\title{
STRATEGIES TO IMPROVE ENGLISH COMMUNICATION FOR ENHANCING EMPLOYABILITY FOR ENGINEERING GRADUATES
}

\author{
Dr. PremilaSwamy D
}

\begin{abstract}
Communication skills and soft skills is one of the prerequisite needs for employment and placements in present day scenario and mastery over the language prompts visibility, leading to better job opportunities. For advancement in career and academics, English language skills, fluency, vocabulary and the art of narration whether oral or written play a pivotal role. Exposure and access to English language leads to acceptance, recognition and better opportunities. For Engineering students, courses like Professional communication or communication skillsarea skill based and value addition course usually taught by Humanities and social sciences department to inculcate and nurture good communication competency among the technical students. Although technical students primarily focus more on their technical expertise, the need for improvising their communication to foster employability during placements is inadvertently realized. However, although Indian students spend almost twelve years of learning English before entering higher education, yet it is observed by recruitment bodies that students fail to articulate their thoughts in the right manner, thus failing to fetch the right jobs. There is some lacuna in our teaching learning methodologies which needs to be seriously addressed. Hence this article analyses these lacunas and explores newer methods and strategies which would be potentially beneficial to achieve communicative competency to seek better employment and thereby bridge the gap between industry and academia.
\end{abstract}

Key words: employability, engineering, curriculum, proficiency, communication skills

\section{Introduction}

English has become the major means of communication across the globe. With the rise of multinational companies and cross-cultural participation, English has become a suitable via media for communication. India being a multilingual country, it is English that connects the masses. It is the acceptable official communication in India. English came to the Indian soil due to colonization and imposition of western education during the $19^{\text {th }}$ century. Lord Macaulay's famous minutes of education administered the need for English education in order to have an elite community who could act as mediators of communication between the English and the Indian people. Thus came English education with the establishment of schools and institutes of higher education to enable western education. Today English in 
India is a must to acquire good administrative positions and jobs of high ranking. For economic activity, trade, administration, excellent command over written and spoken communication is a must. Professionals like Engineers need English communication skills to work and manage with their teams, carry out discussions, making strategies, planning, execution and presentation of ideas and critical analysis. In present day context, English language no doubt plays a substantial role in higher education and administration of private and government organizations. English has occupied a significant place and plays a pivotal role for change in India (Graddol, 2010).

English being a foreign and non-native language, Indian users need to be formally trained in the language unlike the mother tongue. Most Engineering students are well versed in their vernacular communication but stumble when they utter English. This proves a hindrance during placements and recruitments. Employers look out for communicative competency, fluency, confidence and other nonverbal skills like positive body language, paralinguistic aspects and so on during recruitment process. Humanities and social sciences department in engineering institutions offer subjects that enable capacity building and nurture inner potential. Globalization and multiculturalism in today's technological era naturally demands the need for good English communication.In engineering intuitions, apart from technical courses subjects like professional communication and communication skills is taught keeping in mind the pressing requirements for employment. It is a common complaint from recruiters during placements that our education system fails to deliver market ready professionals who can fit into the real world and handle situations at ease. Unfortunately, a greater number of engineering graduates in India find difficult to speak or write in English with fluency and accuracy. In most engineering colleges across India, English is taught at I year level with the prime target being to nurture listening, speaking, reading and writing skills. Although an engineering graduate undergoes professional training for four years and becomes a technically certified engineer, his or her achievement in finding suitable jobs is still subject to doubt. This is primarily due to lack of effective communication skills. A research published in 2018 says that only 5\% to 6\% technical graduates achieve the academic level from where the market can mould them to become a good professional ("94\% of engineering graduates", n.d.). Students fail in constructing grammatically correct sentences in terms of tenses or prepositions while speaking or writing. Even while drafting official letters, documents or project reports, students tend to make lot of errors. They are not able to handle such situations at ease. This gap in teaching and learning strategies needs to be addressed. This forms the very basis of this research article. Identifying innovative strategies of learning English for the target group, i.e. technical students is the objective of this article.

\section{Discussion \& Analysis}

Some of the common problems faced in the Indian classroom scenario are: lack of trained faculty in ELT methodologies as most belong to the literature background, crowded and heterogeneous classroom, fixed syllabus and time duration, exam and marks based attitude among students and improper framework of syllabus. Although engineering intuitions boast about inculcating leadership skills, critical and creative thinking and value-based education in their vision/mission statements and program outcomes displayed on boards at entrances, yet 
there is no serious output in reality.Humanities departments in engineering campuses is usually seen as a supporting department and often neglected as it does not involve in teaching technical subjects. This kind of attitude discourages faculty to come with innovative ideas for exploration. Institution, faculty and student perspective and attitude towards Humanities subjectsrequiresreorientation for constructive growth and capacity building. Considering new education policy 2020 where the emphasis is towards the role of Humanities subjects in fostering value addition, skill based and blended education system, Humanities courses in Engineering institutions need to rework on the curriculum togenerate employability. This article will thus prove useful as it systematically chalks out suitable strategies to adopt in the English classroom discourses so that the objective is fulfilled.

It is clear that a person with good command over the English language along with technical expertise is sure to handle tasks comfortably, gain visibility and thereby suitably place themselves in higher positions.A study undertaken by Gregorio et al. (2019) on the imperative employability skills for future marketing professionals points out five employability skill categories and twenty-nine skills and capabilities. Efficient communication skill is one of them. Another study by Newnam and Goodebec (2019) underlines on the positive implications of effective communication practices in the workplace. Communication related strategies were categorized as three headings: task related communication, relationship related communication and safety related communication. Erickson (2015) focussed on relation between communication and employee retention. He concluded that besides other factors, an employee must focus enriching professional skills which includes communication skills for sustainability in a competitive environment.Many research studies endorse the need for Mathematics, Physics and the engineering sciences as the foundation for engineering practice, but at the same time recognize the value of professional skills such as communication, team-work, project management, and professional ethics - as well as broader environmental and societal issues - that have been neglected in engineering programmes (e.g., Ramadi, Ramadi, and Nasr 2015).There is dearth need for paradigm shift in pedagogical curriculum makeover to enhance engineering knowledge and professional skills. An interdependent relationship between engineering knowledge and professional skills that enables engineering graduates to attain employability needs to be considered. These studies directly convey the need for effective communication skills to seek job opportunities.

Considering the above theoretical survey on the significance of English communication, this article now brings some of the relevant ways of inculcating communication skills for engineering graduates.

\section{Developing listening skills}

Listening is prerequisite for language acquisition as it promotes other skills of communication i.e., speaking, reading and writing abilities. The more the learner is acquainted with the sounds of English language and native speakers, his or her learning capacity increases. Listening to documentaries, movies and speeches that relates to their area of study can be considered in the classroom teaching methods. Students can be asked to observe the speech sounds and get into further discussion. 
Astorga (2015) explored the connection between learning proficiency and speech development and testified that the better listening skills facilitate speaking abilities of the learner.

\section{Inculcating reading habits}

In today's techno savvy world, reading habits of students have come down. Engineering students tend to read only the academic books and do not go beyond the texts. Even if they read, they do not read any classic texts that may develop their vocabulary and thinking capacities. Hence while framing the curriculum, the syllabus must clearly indicate some valuable books under 'suggested reading' and keep those books in the library. The teacher should also ask students to at time read texts aloud so that words get registered in their mind. Teachers can also ask learners to summarize or rewrite what they have read and understood. A study undertaken by MalgorzataMarzec-Stawiarska (2016) discusses the development of students' reading skills by assessing their level of comprehension before and after taking an EFL course on the aspect of paraphrasing a content. The study revealed a drastic improvement in reading skills among the participants. Hence, cultivating reading habits through good pieces of writing should be administered at the college level.

\section{Learning Phonetics}

Clear articulation of words with proper pronunciation is significant for acceptable communication. Teaching the English phonetics enables students to spell out the words in correct accent. Right usage of phonetics brings in clarity and understandability. In his book chapter entitled "Phonetics: Precursors to modern approaches" in the book, Concise History of Language Sciences, Kemp (1995) has articulated the need for phonetics to better our English communication. Study of phonetics is a scientific way of learning the language and hence it needs to be exposed to the Indian students of higher education.

\section{Encouraging group discussions}

A group discussion is one aspect which is used by employers to test communication, leadership skills, critical thinking abilities and confidence. Involving students in group participation will give scope for self-improvement in terms of speaking abilities. It provides a platform for learners to overcome fear, nervousness and gradually make them better performers.

\section{Enriching vocabulary and grammar}

Engineering graduates require good vocabulary and grammatical skills to compose project reports, document materials, draft letters and so on. Hence a thorough knowledge on tenses, parts of speech, words commonly confused, usage of prepositions etc is essential. Enriching vocabulary by reading, listening and writing will help learners in mastering the language. According to Bayram Pekoz (2008), the teacher should bring grammar instruction to life, stimulate interest in the topic, and raise awareness by providing a reason for learning. 


\section{Using literature in the classroom: science fictions \& plays}

One interesting factor missed in Indian curriculum is the need for blended learning. A language classroom can be made an interesting study environment when the teacher is able to cite various passages from literature. When a new word is introduced, the teacher can give a reference of it from any piece of poetry or fiction. For engineering students, reading science fiction and using science fiction as a text for discourse and analysis will not only enable critical thinking abilities but also build language competency. Suitable science fiction movies and fiction can be used for developing communication. This act of blending literature and language will generate interest, curiosity and better learning environment. For example, Amitav Ghosh's The Calcutta Chromosome addresses various issues related to biomedical which could interest chemical or biotech engineering students.

\section{Developing writing abilities}

Engineering students normally tend to work more on numerical and problem solving leaving less scope to construct paragraphs. It is only in the English classes, they are asked to compose paragraphs, articles, essays and various forms of writing. Identifying right choice of words, punctuation, figures of speech, grammatical form of construction, using appropriate conjunctions would prove beneficial in enhancing the art of writing. The learner needs to be acquainted with various connectives and conjunctions so that unity, coherence is achieved to derive meaningful paragraphs. Abigail B. Calkin (2018) established that the process of writing (generating new ideas, thinking about writing) and the products are dependent on the precise use of grammar and can be analysed behaviourally. Behavioural changes can be captured in terms of writing abilities.

\section{Nurturing presentation skill}

One of the significant requirements of engineering graduates is to present their ideas and thoughts in a systematic formal way in order to inform, persuade or make a comparative analysis. Students should be accustomed to various nonverbal cues like body language, paralinguistic factors, use of pauses etc along with their language skills in order to express with confidence and clarity. First the learner needs to be trained in a professional manner regarding the good habits of presentation and then suitable tasks to be given for practice.

\section{Creative writing}

Creative writing sessions and workshops will set in participatory zeal amongst students. Students would enjoy taking a break from routine academics. Good writings collected from the students can be published to encourage them to take their creative skills further. Notable creative writers in English and regional languages can be invited to deliver talks and conduct workshops. 


\section{Online courses}

Technology enabled online classes through MOOC courses like NPTEL (National Programme on Technology Enhanced Learning) has diversified online courses which the students can undergo. NPTEL courses like Soft skills, Enhancing Soft skills and Personality, Technical English etc. offered by IIT faculty members are reservoirs of information and a great source of knowledge for engineering students. These courses can be considered as assignment activity, credit course or add on course to encourage student participation. In their investigation, Gillani and Eynon (2014) concluded that massive open online courses (MOOCs) play an extremely important role in higher education with their empirical research that explores the realities of interacting and learning in such communication courses. Considering this, institutions can encourage students to take up such personality development online courses offered by NPTEL that would benefit them at large.

\section{Conclusion}

The identified methods of teaching learning practices will enable diversified English learning. The above-mentioned strategies would prove beneficial for the learners in getting the necessary command over English language and thus paving way for employment. In a heterogeneous Indian classroom scenario where students come from various backgrounds, the teacher needs to first understand this diversity and set in a platform to make learning easier. Both the teacher and the learner must be equally prepared to experiment new strategies of mastering the language and make the teaching learning process impactful. Identifying the weakness of the learner is the primary task and then accordingly English can be familiarized based on their exposure level. It is observed that the teaching-learning process followed in first year English classes requires a thorough makeover and many teachers require ESP (English for specific purposes) training to equip the engineering students for employability. The findings and strategies suggested in this article substantiate the recommendation of Paul Spence that English courses need to incorporate English communicative events within a syllabus to bridge the gap between the university and the workplace (Spence \& Liu, 2013).Thus, the identified strategies along with proper encouragement and kindling of interest among students and faculty would prove helpful in bridging the gap between industry and academia. 


\section{Works Cited}

Astorga, Erickzon Dany. "The relationship between listening proficiency and speaking improvement in higher education: Considerations in assessing speaking and listening." Higher Learning Research Communications, DOI: https://doi.org/10.18870/hlrc.v5i2.236

Calkin, Abigail B. "Writing on writing." International Journal of Educational Research, vol. 87, 2018, 127-137.

Erickson, Robin Adair. "Communication and Employee Retention”, The International Encycopedia of Interpersonal Communication, https://doi.org/10.1002/9781118540190.wbeic239

Gillani, Nabeel and Rebecca Eynon, "Communication patterns in massively open online courses."The Internet and Higher Education, vol.23, 2014, 18-26.

Graddol, D. English Next, India. New Delhi: British Council, 2010.

Gregorio, Angelo Di et al. "Employability skills for future marketing professionals." European Management Journal, vol 37, no. 3, 2019, 251-258.

Kemp, J A. "Phonetics: precursors to modern approaches", Concise History of Language Sciences, 1995, 371-388. DOI: https://doi.org/10.1016/B978-0-08-042580-1.50061-1

Newnam, Sharon and NatassiaGoodebc, "Communication in the workplace: Defining the conversations of supervisors," Journal of Safety Research, vol. 70, 2019, 19-23.

Pekoz, B. Integrating grammar for communicative language teaching. The Internet TESL journal, XIV (10), 2008. Retrieved from http://iteslj.org/Techniques/Pekoz-Grammar.html

Ramadi, Eric, Serge Ramadi, and Karim Nasr. "Engineering Graduates' Skill Sets in the MENA Region: A Gap Analysis of Industry Expectations and Satisfaction." European Journal of Engineering Education 41(1): 2015, 34-52.

Spence, P., \& Liu, G. Engineering English and the high-tech industry: A case study of an English needs analysis of process integration engineers at a semiconductor manufacturing company in Taiwan. English for specific purposes, 32(2), 2013, 97-109. http://dx.doi.org/10.1016/j.esp.2012.11.003

Stawiarska, MałgorzataMarzec. "The influence of summary writing on the development of reading skills in a foreign language", System, vol. 59, 2016, 90-99.

\section{Dr.PremilaSwamy D Assistant Professor Department of Humanities Ramaiah Institute of Technology, MSRIT Post Bangalore, India \\ Email: dpremilaswami@gmail.com}

